\title{
NOTES
}

DOI http://dx.doi.org/10.4314/mlr.v7i1.9

\section{Notes ON THE SALIENT FEATURES OF TAX LIENS UNDER ETHIOPIAN LAW}

\begin{abstract}
Kinfe Micheal Yilma *
\section{Introduction}

"Tax Liens are not ordinary liens - they are liens of a sovereignty, and a sovereignty can do no wrong" (Bernard Wolson)
\end{abstract}

Tax systems are continuously changing as countries align their tax systems with evolving economic, political, and administrative conditions. ${ }^{1}$ Ethiopia has also pursued this track of tax reform following the shift in the economic policy of the government. Since 2002, The Ethiopian tax reform has brought about significant changes to the enforcement aspect of the tax system. The reform includes introducing tax lien into the Ethiopian tax law regime. Tax lien is literarily a scheme of charging the asset of delinquent taxpayers until the tax already due is paid. $^{2}$

Although one can say little about tax liens under the Ethiopian tax law regime and the practice, the concept is recognized with its own features. The introduction of tax liens has lifted the tax authority from an ordinary creditor to a secured lien holder or creditor. This, coupled with the power in tax foreclosures, ${ }^{3}$ was a clear departure in the realm of tax enforcement under Ethiopian law.

* Lecturer, Hawassa University School of Law, LLB (Addis Ababa University), LLM (University of Oslo).

${ }^{1}$ John Norregaard and Tehmina Khan (2007), 'Tax Policy: Recent Trends and Coming Challenges', IMF Working Paper, WP/07/274, p. 3; available online at $<$ http://papers.ssrn.com/sol3/papers.cfm?abstract_id=1116187> (Accessed on May 21, 2013).

${ }^{2}$ Delinquent taxes are taxes already due but not yet paid by the taxpayer; the defaulting taxpayer is referred to as a delinquent taxpayer.

${ }^{3}$ Tax foreclosure is a unilateral tax enforcement mechanism by which tax authorities enforce delinquent taxes without direct judicial involvement by seizing and selling delinquent taxpayers property. See, Kinfe Micheal, "An Introduction to the Ethiopian Law of Tax Foreclosure: A Commentary", Abyssinia Law, at 9, available at $<$ http://www.abyssinialaw.com/uploads/The_Ethiopian_Tax_Foreclosure_Regime_3_.pdf $>$; 
Previously, the tax authority had to seek judicial execution to have delinquent taxes enforced. ${ }^{4}$ And, judicial executions had proven to be timetaking and costly in recovering taxes thereby leading to huge backlog of cases.

This short note deals with the nature, features and effects of the tax liens under the Ethiopian tax laws. Owing to considerable commonalities with the Ethiopian law of tax enforcement, the experience of the US is consulted. The first section of the note briefly introduces the meaning and nature of tax liens followed by a discussion on the salient features of the Ethiopian tax lien regime in the second section. The procedures in the creation of tax liens are outlined in the third section.

\section{Meaning and Nature of Tax Liens}

Security may be created either by a contract or may arise out of the operation of the law. Security created by contract often takes the form of 'mortgage', 'pledge', or 'charge'. Where it arises out of the operation of law, it is referred to as 'lien' ${ }^{6}$ Lien is a legal right or interest that a creditor has in another's property lasting usually until the debt or the duty that it secures is satisfied (sic). ${ }^{7}$ In cases of lien, though the creditor obtains propriety right over the subject matter of the security, s/he may not obtain possession of the property. ${ }^{8}$ Tax Lien is among the various forms of lien ${ }^{9}$ by which tax authorities enforce payment of delinquent taxes by charging over the assets of the defaulting taxpayer. It is simply a security established by law in favour of the tax collector upon default of tax

The Black's Law Dictionary describes it as a public authority's seizure and sale of the property for non-payment of taxes. See Garner, infra note 7, p. 658.

4 See, A Proclamation To Provide For Payment of Income Tax, Articles 62 and 63, 1963, Proclamation No. 173 of 1963, Neg. Gaz., 20 ${ }^{\text {th }}$ year, No. 13. See also, Bekelle Haile Selassie (1992), "Salient Features of the Major Ethiopian Income Tax Laws", 15 Journal of Ethiopian Law, at 53.

${ }^{5}$ Mortgage refers to a right granted to the creditor over the property of his/her debtor, for the security of his/her debt. In almost all cases, mortgage gives the creditor the power of having the property seized and sold up on default on the debtor's part. It may arise out of the operation of the law (legal mortgage), judgment of a court of law (judicial mortgage), or contractually (contractual mortgage). See generally, Bernardt, infra note 42, pp. 362 et esq.

${ }^{6}$ Wayne Clark (2002), Fisher and Lightwood's Law of Mortgage (Butterworth, Lexis Nexis), $7^{\text {th }}$ edition, p. 4.

${ }^{7}$ Brayan Garner (ed., 1999), Black's Law Dictionary (West Publishing Co.), $7^{\text {th }}$ edition, p. 933.

${ }^{8}$ Ibid.

${ }^{9}$ Agent's Lien, Accountants Lien, Banker's Lien, Choate Lien, Common Law Lien, Mechanic Lien, Agricultural Lien, Attachment Lien, Judicial Lien are among the various types of liens in different jurisdictions. For a list of other types of lien, see Garner, supra note 7, pp. 933-936. 
payments. ${ }^{10}$ Tax liens can be seen as a legal alternative to tax foreclosure in the tax enforcement process. ${ }^{11}$

In many common law countries, a tax lien attaches all properties of the taxpayer including rights to property in the hands of third parties that any private creditor could seize to satisfy his/her debt. ${ }^{12}$ Moreover, the lien extends to items of property which are subject to distrait and to property exempt from the claims of creditors. ${ }^{13}$ In no case can the lien extend beyond the right of the taxpayer in the property against which enforcement is sought. ${ }^{14}$

Some Comparative tax law experts recommend that the lien shall be established against all property and rights to property, whether movable or immovable, belonging to the taxpayer. ${ }^{15}$ What property or rights to property belong to the taxpayer at the moment of the creation of the tax lien is also another important consideration. ${ }^{16}$ This would require authorities to make meticulous search of property rights of the taxpayers from various sources.

Also notable is that the intention of the legislature to create a tax lien must clearly be provided in the law establishing the same. The power to tax or sell does not give rise to the authority to create a lien for taxes. ${ }^{17}$ In this context, the Ethiopian tax law enforcement fails to clearly enunciate the scope and particulars of tax lien. As will be explained in what follows, it is regulated so loosely and indeed with some unique features.

${ }^{10}$ Words and Phrases (1965), Vol. 41(West Publishing Co.), permanent edition, p. 321.

${ }^{11}$ For a detailed elaboration on the distinction between tax foreclosure and tax liens under Ethiopian tax law, see Kinfe Micheal Yilma (2012), "Tax Foreclosure and Tax Liens: Where Lies the Line - A Case Comment", 2 Bahir Dar University Journal of Law 2, at 291-302.

${ }^{12}$ Corpus Juris Secundum: Complete Restatement of American Law (1954), Taxation, Vol. 84, (Brooklyn NY: American Law Book Company), p. 1182.

${ }^{13} 2^{\text {nd }}$ American Jurisprudence (1967), Federal Tax Enforcement, Vol. 35 (The Lawyers Cooperative Publishing Co), p. 20. See below for properties subject to tax lien under the Ethiopian tax laws.

${ }^{14}$ Ibid.

${ }^{15}$ Richard Gordon, Law of Tax Administration and Procedure, in Victor Thuronyi (ed., 2000), Tax Law Design and Drafting (Kluwer Law International), p. 108; See also, Paul Anderson (1953), "Federal Tax Liens: Their Nature and Priority", 41 California Law Review 241, at 245.

${ }^{16}$ Bernard Wolson (1959/60), "'Federal Tax Liens -A Study in Confusion and Confiscation", 43 Marquette Law Review 191, at 180.

${ }^{17}$ Corpus Juris Secundum, supra note 12, p. 1182. 


\section{The Salient Features of the Ethiopian Tax Lien Regime}

As alluded to above, the Ethiopian tax law regime recognizes tax lien as one means of enforcing payment of taxes. ${ }^{18}$ This is provided in almost all of the tax laws of the country. ${ }^{19}$ The legislature has opted to regulate tax lien in a single

${ }^{18}$ Note that concerned personnel of the Ethiopian Revenues and Customs Authority (hereafter, the tax authority) do however seem to be alien to the concept and even to its recognition under the tax laws. Interestingly, some of the legal officers told the author that the provision governing tax lien (Art. 80 of the income tax proclamation) is just a sheer provision of 'attachment' which is stipulated in the directive issued by the Ministry of Finance and Economic Development to regulate tax foreclosures. See, “\%नC Ponhl.

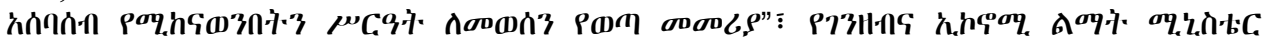
$§ 1996$ E.C, Art. 11. There have also been some incidents which partly evidenced this oblivion towards tax liens. One is a recent income tax amendment legislation that imposes an obligation on commercial banks to require all potential borrowers to furnish a tax clearance certificate evidencing discharge of any tax obligations before extending any loan and hence receiving the assets of the persons as collateral. See, Art. 2(3), A Proclamation to Amend the Income Tax Proclamation, Federal Neg. Gaz., $17^{\text {th }}$ year, No. 3, Proclamation No. 693/2010. See also news reports, Capital, English Business Weekly, 'Swift Legislation Orders Banks to ensure Collaterals are free from Tax Dues', November 21, 2010 and Awramba Times, Amharic Weekly, 'Tax is To be Charged on Windfall Gains', Hidar 11/2003 E.C. (Translation Mine). It has been reportedly stated at the time of parliamentary deliberation on the draft bill that the main rational behind imposing such an onus on banks is to secure the revenue interest of the government which has been at peril due to priority claim by banks. The desire and the subsequent legislative action to impose this obligation on banks appear to have resulted from legislature's (probably the sponsors of the bill) unawareness of tax lien. Tax lien, as regulated under Art 80 of the income tax law, was sufficient to enforce delinquent taxes. Tax lien already granted the tax authority priority right over the assets of delinquent taxpayers' property. All what is needed is just to make timely fixation of the lien so that the revenue interest of the government may well be secured. It is less likely that the sponsors of the law were well aware of the nature, features and effects of tax lien while introducing the amendment. Given the very purpose of tax lien to give priority in the face of multiple claims by other creditors, the imposition of this obligation on banks is at best unnecessary. And, one cannot but forward his reasonable conjecture that tax lien is unknown evil in the tax legislations that awaits loud awakening bell. Note that a sort of similar obligation was already provided in the amended income tax law which makes the whole reiteration of the obligation nonsensical. See, Art. 41(2), income tax proclamation, infra note 22. However, all what could be thought as new is just the specific mention made to banks in the amendment law. Note also that an illuminating directive has recently been issued by the tax authority.

${ }^{19}$ See, for instance, Art 80 of the Income Tax Proclamation No. 286/2002, Art 32 of the Value Added Tax Proclamation No.285/2002, Art 11 of the Excise Tax Proclamation No. 307/2002 and Art 14 of the Turnover Proclamation No. 308/2002. For the 
article and subordinate legislation has not yet been enacted. The principal provision governing tax lien reads:

"From the date on which the tax becomes due and payable under this proclamation, subject to the prior secured claims of creditors, the Authority has preferential claim over all other claims upon the assets of the person liable to pay the tax until the tax is paid". ${ }^{20}$

Pursuant to the above provision, the tax authority gains lien right over the asset of delinquent taxpayers from the date taxes are due and payable. ${ }^{21}$ Normally, a tax, for instance income tax, becomes due and hence payable on the various dates specified in the relevant tax law. ${ }^{22}$ The lien right of the tax authority is, however, subject to prior secured claims of other creditors. That is, if there exists a senior lien on the property of the taxpayer, the interest of the tax authority will be subordinate to those prior secured claims.

Moreover, the sub-article goes on to state that the lien right of the tax authority continues until the tax is paid. It is in the very nature of liens that the encumbrance operates until the debt it secures is fully discharged. Ethiopian law, however, deviates from the law of other countries. According to the US Internal Revenue Code, for instance, the duration of the lien right of the government is not restricted ... 'until the tax liability is satisfied', but also the Code prescribes another disjunctive lien period, i.e. 'or until the tax liability becomes unenforceable by reason of lapse of time'.23 The Ethiopian law disregards the second limb of the prescription. ${ }^{24}$ This seems to support arguments which criticize the Ethiopian tax law regime for having no clear guideline on period of limitation to enforce tax claims. ${ }^{25}$

purpose of this note, all of the references are made to the income tax proclamation (Hereafter, ITP).

${ }^{20}$ ITP, infra note 22, Art. 80(1).

${ }^{21}$ It is generally recommended that the law should provide that a tax assessment is a charge or lien that constitutes a security interest in the taxpayer's property in favor of the government. See, Gordon, supra note 15, p. 108.

${ }^{22}$ Income Tax Proclamation No. 286/2002, Art 74, Fed. Neg. Gaz., $8^{\text {th }}$ year, No. 34; see cumulatively Arts 66-68 of ITP for specific periods when payment of the various schedular income taxes have to be made.

${ }^{23} 2^{\text {nd }}$ American Jurisprudence (2001), Federal Tax Enforcement, Vol. 35 (The Lawyers Cooperative Publishing Co.), p. 261.

${ }^{24}$ In connection with period of limitation for enforcement of tax claims, I have argued elsewhere that the existing Ethiopian law of tax enforcement doesn't set a clear period of limitation to enforce unpaid delinquent taxes. See, Kinfe Micheal Yilma (2009), Tax Foreclosure and Securitization: The Law and the Practice, Unpublished Senior Thesis, AAU Law School, pp. 49-53.

${ }^{25}$ See below the discussion on the period of limitation for enforcing delinquent taxes through tax lien. 
Also noteworthy in the same sub-article relates to properties subject to tax lien. It is crudely provided that the lien charges on the assets of the person liable. Types of property or rights to property subject to tax lien are not clearly specified. In other jurisdictions, the transferability by a creditor of the property suffices for it to be encumbered by tax lien. ${ }^{26}$ Under this rule, a tax lien attaches any property which could serve as collateral for a private security arrangement. ${ }^{27}$ At first sight, one might be inclined to construe the position of the Ethiopian law as allowing encumbrance on all the assets of the delinquent taxpayer. Unlike the tax foreclosure rules ${ }^{28}$, the law does not also provide for exemption rules that put certain property off-limits of encumbrance by tax liens.

One major and perhaps a distinguishing feature of the Ethiopian tax lien regime concerns the ultimate effect that the law accords to tax liens. It is provided that a 'notice served to the property registering authority ordering the registration of the interest of the tax authority will serve as an instrument of mortgage'. ${ }^{29}$ (Emphasis supplied). This stipulation, in effect, makes the tax authority a mortgagee (sic) over the asset on which a lien is perfected. The same sub-article further goes on to state that the registration shall, for all legal purposes, operate as a legal mortgage ${ }^{30}$ (sic).

It flows, therefore, from this stipulation that all the legal conditions and effects of legal mortgage regulated under the Ethiopian Civil Code applies, mutatis mutandis, to tax liens created from the day taxes become due and payable. ${ }^{31}$ This shows that the Ethiopian tax lien regime has a distinct feature

26 "Property Subject to the Federal Tax lien", 77 Harvard Law Review 8, 1964, at 1487.

${ }^{27}$ Ibid. See also, Bernard, supra note 16, at 183.

${ }^{28}$ See Art 77(7) of the ITP which provides for properties not subject to seizure.

${ }^{29}$ ITP, supra note 22, Art 80(4).

${ }^{30}$ Legal mortgage is one variant of mortgage created by the operation of the law without the aid of any agreement. The most common instances under which a legal mortgage may arise include; a legal mortgage that minor persons, interdicted persons and absentees have on the property of their tutors and curators as a security for their administration. See, Garner, supra note 7, p. 1028. The various Ethiopian laws also set forth four major instances of legal mortgage, namely, 'legal mortgage of copartitioners (Art 3043 of the Civil Code), 'legal mortgage of sellers of an immovable' (Art 3042 of the Civil Code), 'legal mortgage for a seller of a business and creditors of a bankrupt trader' (Art 172 of the Commercial Code), and 'legal mortgage of the tax authority on the delinquent taxpayers property' (Art 80(4) of ITP). The fourth instance under which a legal mortgage arises is perhaps the most recent and probably peculiar to the Ethiopian case by which the tax laws add a new realm of legal mortgage.

${ }^{31}$ It is good to note that the Income tax proclamation, under its definitional article, Art 2, explicitly invites the applicability of the terms defined in other laws of Ethiopia, the civil code included, unless a different meaning is expressly provided. Hence, in 
which slightly deviates from the very nature of lien, one that charges assets of the debtor only until the debt is paid. ${ }^{32}$

The concept of tax liens under the Ethiopian legal regime consequently has the following effects. First, the tax authority, as a mortgagee, may demand to be paid out of the proceeds of the sale of the immovable (of the delinquent taxpayer) in priority of other creditors ${ }^{33}$ subject to the exception stated earlier. Here, it is interesting to note that the mortgagee cannot sell the property by its own unilateral action. ${ }^{34}$

The second effect relates to properties subject to the tax lien. As stated above, Article 80 of the Income Tax Proclamation, i.e. the principal provision creating tax lien, seems to encumber all the property and right to property of the delinquent taxpayer. It generally states '... upon the assets ...'. However, the features of tax lien in Ethiopia slightly narrow down the kind of property subject to tax lien. Article of the Ethiopian Civil Code governs property liable to mortgage, legal mortgage and hence tax lien. According to Article 3047(1) a "mortgage may charge an immovable only" and Article 3047(1) provides that this shall not affect "the provisions of [the Civil] Code or special laws whereby certain kinds of movables may be mortgaged".

Thus a mortgage mainly charges immovable property save certain kinds of movable things. It is to be noted that mortgage charges only some movables and shall not apply to most movables, rights to property and other intangible rights

our case Art 2 or any other definitional provision in the law has not given a different meaning to the phrase under consideration, i.e. legal mortgage.

32 This peculiarity that the Ethiopian tax lien regime features casts doubt on whether it has been introduced after it has been properly thought through. Legal mortgage, as regulated under the Ethiopian Civil Code, is enforceable through court procedure, one thought to have been secluded from the tax enforcement continuum. And, this tempts one to question why the drafters or rather the sponsors of the law wanted to introduce non-judicial tax-enforcement procedures on the one hand, and at the same time reinstate judicial procedures through the phrase 'legal mortgage'. It is highly probable that the phrase 'legal mortgage' might have slipped into the provision incidentally and unintentionally. Otherwise, one can hardly think of such contradictory stipulation.

${ }^{33}$ Civil Code of the Empire of Ethiopia, 1960, Art 3041, Neg. Gaz., Extraordinary Issue, $19^{\text {th }}$ year, No. 2, Proclamation No. 165.

${ }^{34}$ The Ethiopian law of security devices dictates one to obtain a 'judicial declaration' authorizing the sale to enforce security. See, Art 3058(1) of the Civil Code, supra note 33. Accordingly, the Ethiopian tax lien regime seems to have invited the judiciary in the tax enforcement process. It reinstates the role of the judiciary which was believed to have been secluded from the enforcement regime. It is to be noted that the delay in the judicial means of recovering delinquent taxes is reportedly one of the main causes for the adoption of self-executing enforcement schemes, tax liens included. 
that the taxpayer may claim from third parties. In this sense, Ethiopian tax liens charge relatively small category of properties.

The third effect of the above conception relates to the duration of the tax authority's mortgage right. It is provided under Art. 3058(1) of the Civil Code that initially a duly registered mortgage takes legal effect for a period of ten years. This period may, however, be prolonged through renewal. ${ }^{35}$

Related to this is the issue of period of limitation ${ }^{36}$ for enforcing delinquent taxes through tax lien. One may dare say that since a legal mortgage is valid for ten years from the date of its registration (having in mind the possibility of renewal), it is possible for the tax authority to enforce its tax claims within the ten years period. The other plausible option is to extend the applicability of Title XII (Arts 1845-1856) of the Ethiopian Civil code.

Since the tax laws create legal mortgage (thereby establishing a mortgageemortgagor relationship), Title XVIII of the Civil code (Contracts Relating to Immovables, which includes mortgages) shall consequently apply. Moreover, Article 1676(1) of the Civil Code allows the application of the general provisions of Title XII (which includes Articles 1845-1856) to contracts regardless of their nature and parties thereto.

Contracts relating to immovables including mortgages are one variant of contracts which Article 1676(1) is referring to. One can thus conclude that the relevant provisions of Title XII (including limitations of actions) can apply for tax claims of the tax authority as per Article 1676(1) of the Civil Code. In sum, tax claims would be barred by period of limitation after ten years as any contractual claim. In spite of the possibility of relying on the above construction, there is indeed the need for clear period of limitation in the relevant laws.

\section{Procedures in Fixing Tax Liens}

As in the case of tax foreclosure, there are also legally prescribed procedures in fixing tax liens. The Ethiopian law sets forth two major requirements: 'notification', and 'registration'. 37

${ }^{35}$ Civil Code, supra note 33, Art 3058(2).

${ }^{36}$ The term limitation, also called 'prescription', signifies the restriction by law of a right of action to a specified period after the lapse of which its enforcement may be denied. See, Bekelle Haile Selassie (1993), "Limitations of Action in relation to the Recovery of Taxes on Income from Sources Chargeable under Schedule C of the Ethiopian Income Tax Proclamation No. 173/1963 (as amended)", 16 Journal of Ethiopian Law, at 141-146.

37 Over and above these two requirements, there has to be in the first place an assessment of the tax due. In order to establish a lien for tax purposes the assessment of the tax must also be valid. See, Corpus Juris Secundum, supra note 12, p. 1182. In 


\subsection{Notification}

The significance of notification in tax enforcement proceedings is a key instrument in communicating in clear terms to the taxpayer that his delinquency is known and that it cannot be tolerated. Two separate phases of notification are provided under the tax laws concerning tax liens. They are; first, 'notification to the delinquent taxpayer' 38 and second, 'notification to the property registering authority. 39

In the first phase of notification, the tax authority informs the taxpayer, in a written notice, its intention to apply to the property registering authority for the latter to register the assets of the former as a security for the payment of the tax. Such notice is served to the taxpayer when the latter is in default of paying the tax due. ${ }^{40}$ In the second phase of notification, the tax authority directs (sic) the registering authority by a written notice to effect the registration of the assets of the taxpayer in proportion to the tax liability. This notification to the registering authority is served when the taxpayer fails to comply with the first notice within 30 days from the date of the notice. ${ }^{41}$

The third implicit phase of notification concerns the one that is served to the public at large or interested third parties. Once notice is served to the registrar to effect the recording of the tax authority's interest, this will consequently but indirectly serve as a de facto notice to the general public particularly to interested third parties. By virtue of charging a subsequent claimant with notice of previously recorded titles, the notice imposes on such persons the practical duty of searching the records. ${ }^{42}$ For instance, since a purchaser will be charged

line with this requirement the Ethiopian law has made it clear that a tax lien shall take effect from the date on which the tax becomes due and payable.

${ }^{38}$ ITP, supra note 22, Art 80(2).

${ }^{39} \mathrm{Id}$, Art 80(3); in addition, there is a third implicit phase of notification viz. 'notification to the general public.'

${ }^{40}$ Ibid.

${ }^{41}$ According to Art 73(2) of ITP a taxpayer would be deemed in default, where the following conditions are satisfied:

I. Where the taxpayer fails to pay the tax due within 30 days from the receipt of the assessment notice or from the date of the decision of the review committee; or

II. Where the period for lodging appeal on the decision of the tax appeal commission has expired; or

III. Where the court of appeal renders its final decision.

It is also interesting to note at this juncture that the notice served to the property registering authority is a direction or order; which seems to suggest that the registering authority is all the time incumbent to effect the registration without any examination thereto.

${ }^{42}$ Roger Bernardt (1993), Real Property in Nutshell (West Publishing Co.), p. 331. 
with notice of what is in the records, every person intending to encumber or buy must search the records first to ascertain the priority of his/her own claim. ${ }^{43}$

\subsection{Registration}

Registration is the second legally set prerequisite in fixing tax liens. In its literary sense, registration, sometimes called recordation, denotes the formal act of investiture whose origin can be traced back to Roman law times. ${ }^{44}$ Registration of security interests is said to be a universal practice throughout the world. ${ }^{45}$ For tax enforcement purposes, the law also provides registration as one basic requirement. The tax authority, as noted above, is authorized to order (sic) the registration of assets belonging to delinquent taxpayers upon default of the latter.

Tax lien must normally be recorded in order for it to rank ahead of other secured claims. ${ }^{46}$ It goes without saying that the lien right of the tax authority hinges on the time when it is filed. As far as the timing is concerned, the rule in many common law jurisdictions is 'first in time, first in right!' According to this rule, a lien will not be valid against any subsequent purchaser or holder of the security interest or a judgment lien creditor unless the notice of the encumbrance thereof is filed.

Hence, if the interest of the tax authority is registered, it would survive any transfer of property (including claims against a good faith purchaser). ${ }^{47}$ The tax authority would remain a secured creditor having mortgage over the asset of the taxpayer until the tax liability is fully settled. However, the phrase '... subject to prior secured claims ...' under Art 80(1) of the Income Tax Proclamation is to be noted with regard to the timing requirement to acquire priority of lien.

\section{Conclusion}

Tax liens and tax foreclosure have enormously reformed recovery of delinquent taxes. The basic features and effects of tax liens in Ethiopia along with the

${ }^{43}$ Ibid, p. 332; yet one may carve out an exception to this rule of recordation on the basis of the principle of possession in good faith which shields good faith purchasers of corporeal chattels from a seller having no valid title thereon without having checked the appropriate register of property. See, for example, Civil Code, supra note 33, Arts 1161-1167.

${ }^{44}$ Yohannes Heroui (2008), 'Registration of Immovable Property Under the Ethiopian Civil Code", 2 Ethiopian Bar Review2, at 76.

${ }^{45}$ The New Encyclopedia Britannica: A Ready Reference (2002), Vol. 4, (Encyclopedia Britannica Inc), $15^{\text {th }}$ edition, at 195.

${ }^{46}$ World Tax Series: Taxation in USA (1963), Harvard Program on Taxation, (Commerce Clearing House Inc), p. 1266.

${ }^{47}$ Evan Hayned (1929), Chattel Mortgage: Right of Creditors When Recordation or Delivery is Delayed, 17California Review, at 52. 
procedural prerequisites of notification and registration have been highlighted. Among others, the possibility of direct judicial involvement in fixing and enforcing the lien is its basic ramification which follows from the treatment of tax lien by Ethiopia's tax laws as a legal mortgage.

This feature of lien departs from the conventional rules on tax liens as the latter are essentially out of court tax enforcement procedures. While the involvement of the judiciary is not a problem per se (it may rather be desired in the midst of risky self-execution processes), the approach does not seem a deliberate and purposeful inclusion. One of the overarching aims of the tax reforms was to rectify the delay in the judicial execution of tax claims. While this was what had been intended, what turned out with the enactment of the laws includes unintended outcomes, the discussion of which is beyond the scope of this note. 